\title{
COMMENT
}

\section{Five Patients with Biochemical and/or Clinical Generalized Glucocorticoid Resistance without Alterations in the Glucocorticoid Receptor Gene*}

\author{
NANNETTE A. T. M. HUIZENGA, PIETER DE LANGE, JAN W. KOPER, \\ WOUTER W. DE HERDER, ROGER ABS, JAN H. L. M. V. KASTEREN, \\ FRANK H. DE JONG, AND STEVEN W. J. LAMBERTS
}

Department of Internal Medicine III (N.A.T.M.H., P.d.L., J.W.K., W.W.d.H., F.H.d.J., S.W.J.L.), University Hospital Dijkzigt, 3015 GD Rotterdam, The Netherlands; Department of Endocrinology (R.A.), University Hospital Antwerp, Antwerp 2650, Belgium; and Department of Pulmonary Diseases (J.H.L.M.v.K.), St. Anna Hospital, 5664 EH Geldrop, The Netherlands

\begin{abstract}
Cortisol resistance (CR) is a rare disease characterized by a generalized reduced sensitivity of end-organs to the actions of glucocorticoids (GCs). GC effects are mediated by the GC receptor (GR). The molecular alterations in CR described thus far were located in the hormone-binding domain of the GR gene. Recent reports of a considerable prevalence of abnormalities in the GR in patients attending the endocrine clinic prompted us to carry out further investigations with respect to GR protein and GR gene in patients attending the endocrine clinic for a broad spectrum of complaints and biochemical evidence suggesting a CR.

In the present study, we describe five patients with biochemical and clinical CR. All patients showed a diurnal rhythm of serum cortisol concentrations (albeit at a high level), an insufficient suppression of serum cortisol concentration in reaction to $1 \mathrm{mg}$ dexamethasone (DEX), and variable degrees of androgen overproduction, in the absence of clinical signs and symptoms of Cushing's syndrome. Three of the four female patients presented with complaints of androgen overproduction, two of them in combination with fatigue. The other female patient had severe steroid-resistant asthma. The only male patient and his son were asymptomatic.
\end{abstract}

In four patients, we investigated receptor protein characteristics on mononuclear leukocytes in a whole cell DEX binding assay and studied the ability of DEX to inhibit mitogen-induced cell proliferation in mononuclear leukocytes in vitro. In all patients investigated we found alterations in receptor number or ligand affinity and/or the ability of DEX to inhibit mitogen-induced cell proliferation.

To investigate the molecular defects leading to the clinical and biochemical pictures in these patients, we screened the GR gene using PCR/single-strand conformational polymorphism/sequence analysis. No GR gene alterations were found in these patients.

In conclusion, the five patients described had clinical and biochemical evidence of $\mathrm{CR}$, but no abnormalities were demonstrated in the GR gene.

Probably, as yet undefined alterations somewhere in the cascade of events starting with ligand binding to the GR protein, and finally resulting in the regulation of the expression of GC responsive genes, or postreceptor defects or interactions with other nuclear factors form the pathophysiologic basis of CR in these patients. (J Clin Endocrinol Metab 85: 2076-2081, 2000)
$\mathrm{C}$ ORTISOL RESISTANCE (CR) is a rare condition characterized by a generalized reduced sensitivity of endorgans to glucocorticoids (GCs). The disease is typified by increased serum cortisol levels, a normal circadian rhythm of cortisol concentrations (albeit at an elevated level), relative resistance of adrenal cortisol suppression to dexamethasone (DEX), and the absence of the clinical stigmata of Cushing's syndrome (1). After the original description of a father and son with CR by Vingerhoeds et al. (2), about 30 symptomatic patients and asymptomatic family members have been identified (1-13). In generalized CR, the decreased sensitivity to

Received June 24, 1999. Revision received December 9, 1999. Accepted December 30, 1999.

Address correspondence and requests for reprints to: Nannette Huizenga, Dijkzigt University Hospital, Afdeling 4-zuid, Dr. Molewaterplein 40, 3015 GD Rotterdam, The Netherlands.

* Supported by a grant from the Dutch Organisation for Scientific Research (NWO). cortisol results in activation of the hypothalamo-pituitaryadrenal (HPA) axis with increased ACTH and cortisol secretion. In most cases, the elevated cortisol levels sufficiently compensate to overcome peripheral CR. The elevated cortisol concentrations are beneficial in these patients, and no signs or symptoms of Cushing's syndrome are present. The clinical presentation of $\mathrm{CR}$ is, in most instances, related to the secondary ACTH-driven overproduction of adrenal androgens and mineralocorticoids. Hypertension and hypokalemic acidosis may develop secondary to overproduction of mineralocorticoids $(1,2)$. In females, the secondary overproduction of adrenal androgens may result in acne, hirsutism, menstrual irregularity, and infertility $(1,6)$. The overproduction of adrenal androgens gives rise to signs of hyperandrogenism in females only because of the much higher gonadal androgen production in males compared with females. In some patients with $\mathrm{CR}$, chronic fatigue is the only symptom (5), probably due to an insufficient overproduction of 
cortisol. Finally, several patients with steroid-resistant asthma have been described, which in two cases seemed to be caused by generalized CR (13).

The biological effects of cortisol are mediated by the GC receptor (GR), a member of the family of intracellular hormone receptors (14), to which the vitamin D and retinoic acid receptors belong as well. These receptors are characterized by a three-domain structure: a carboxy-terminal ligand-binding domain, a central DNA-binding domain, and an N-terminal domain responsible for the interactions with other transcription factors (14). Hormone-bound GRs translocate to the nucleus and regulate the expression of GC-responsive genes.

It has become clear from previous studies that the molecular basis of CR may be located in the GR gene. Up to the present, this has been elucidated in six different kindreds (15-20), in which mutations in the hormone-binding domain of the GR gene seemed to be the cause of CR.

Because of the large variation in clinical manifestation of $\mathrm{CR}$, the disease might be less rare than previously thought. In six patients described previously, at least three different clinical forms of CR could be identified (1).

In the present study, we report five additional patients with very diverse clinical presentations. Eventually, in all patients clinical and/or biochemical CR was diagnosed. Using PCR/single-strand conformational polymorphism (SSCP) and sequence analysis, we screened the GR gene in these patients for alterations, to characterize the CR on the molecular level as well. No evidence for mutations in the GR gene was found in any of the patients, however. Suggestions for other possible mechanisms of $\mathrm{CR}$ in these individuals are made.

\section{Materials and Methods \\ Biochemical determinations}

The diagnostic procedures used in measuring the activity and responsiveness of the HPA axis in the patients tested in our own clinic have been described previously $(21,22)$ Circulating and urinary cortisol, $\mathrm{ACTH}$, desoxycortisol, androstenedione, dehydroepiandrosterone, dehydroepiandrosterone sulfate, and testosterone levels were determined by RIA kits. The inter- and intra-assay variations of these determinations have been reported previously (1).

\section{Peripheral blood mononuclear cells}

Blood $(40 \mathrm{~mL})$ was drawn into heparinized tubes between $0800 \mathrm{~h}$ and $0900 \mathrm{~h}$ by vena puncture. Peripheral blood mononuclear leukocytes (PBMLs) were isolated as described previously (23). The blood was diluted 2-fold with saline and layered over Ficoll-Hypaque (Pharmacia, Uppsala, Sweden). The PBML-enriched interphase was isolated and washed twice with saline. The final cell pellet was resuspended in $15 \mathrm{~mL}$ RPMI-1640 medium (Gibco Europe, Breda, The Netherlands), containing $15 \mathrm{~mm}$ HEPES, 10\% charcoal-absorbed FCS (Amstelstad/Flow, Zwanenburg, The Netherlands), $2 \mathrm{~mm}$ glutamine, $100 \mathrm{U} / \mathrm{mL}$ penicillin, $100 \mathrm{mg} / \mathrm{mL}$ streptomycin, and $1.5 \mathrm{mg} / \mathrm{mL}$ fungizone. The cells were incubated for $30 \mathrm{~min}$ at $37 \mathrm{C}$ in a shaking water bath to remove endogenous cortisol. The cell suspension was centrifuged and resuspended in $15 \mathrm{~mL}$ medium. This procedure was repeated twice more. Finally, the cells were resuspended at a density of $2.5-10 \times 10^{6}$ cells per $\mathrm{mL}$ in the medium.

\section{Whole cell DEX-binding assay}

The whole cell DEX-binding assay was performed as described previously (23). Briefly, incubation was started in a volume of $240 \mu \mathrm{L}$ $\left(0.5-2 \times 10^{6}\right.$ cells) containing ${ }^{3} \mathrm{H}-\mathrm{DEX}$ at concentrations of $1.3-40 \mathrm{nM}$ without (total binding) and with (nonspecific binding) a 400-fold excess of unlabeled DEX. Two tubes without labeled DEX were incubated under the same conditions for determination of cell number and viability at the end of the procedure. The tubes were incubated during $1 \mathrm{~h}$ at 30 $\mathrm{C}$ in a shaking water bath. The incubation was stopped by the addition of $2 \mathrm{~mL}$ cold saline, followed by centrifugation and two washing steps. Finally, the cells were resuspended in $250 \mu \mathrm{l}$ medium. Radioactivity in $200 \mu \mathrm{l}$ of this suspension was counted in a liquid scintillation counter. Specific binding was calculated by subtracting nonspecific binding from total binding. Receptor number and ligand affinity $\left(1 / K_{d}\right)$ were calculated from the data using the method of Scatchard (24). Normal values for the number of receptors per cell $\left(6352 \pm 310\right.$ per cell) and $K_{d}(7.7 \pm$ $0.4 \mathrm{nmol} / \mathrm{L})$ were described previously $(1,25)$

\section{Inhibition of mitogen-stimulated incorporation of [3H]- thymidine by DEX}

The sensitivity of mononuclear leukocytes to the inhibition of phytohaemagglutinin-stimulated incorporation of $\left[{ }^{3} \mathrm{H}\right]$-thymidine by DEX was determined, as described previously (1). After isolation, mononuclear leukocytes were seeded, and phytohaemagglutinin $(5 \mu \mathrm{g} / \mathrm{mL})$ and DEX in nine concentrations between 0 and $1000 \mathrm{nmol} / \mathrm{L}$ were added. The cells were incubated at $37 \mathrm{C}$ during $96 \mathrm{~h}$. The last 4 hours of incubation was in the presence of $0.5 \mu \mathrm{Ci}$ of $\left[{ }^{3} \mathrm{H}\right]$-thymidine. At the end of the incubation, the cells were harvested and washed, and incorporated $\left[{ }^{3} \mathrm{H}\right]$-thymidine was measured by liquid scintillation counting. The concentration of DEX necessary to achieve $50 \%$ of the maximal inhibition $\left(\mathrm{IC}_{50}\right)$ was calculated. Normal values for $\mathrm{IC}_{50}(<15 \mathrm{nmol} / \mathrm{L})$ were described previously $(1,25)$

\section{PCR / SSCP analysis of the GR gene}

DNA was isolated from peripheral blood leukocytes using standard techniques. PCR amplification of the GR gene was carried out using primer sequences and amplification conditions previously described by Karl et al. (16). SSCP analysis of the PCR products was carried out using $0.5 \times$ MDE polyacrylamide gels (J.T. Baker Chemicals, Deventer, The Netherlands) at $4 \mathrm{C}$ in the presence and absence of $5 \%$ glycerol, generally as described by Orita et al. (26). DNA fragments displaying an abnormal migration pattern during SSCP analysis were subject to direct sequencing using a modified Sanger-dideoxynucleotide chain termination method $(16,27)$. In all patients, a second PCR amplification of the exons 2 and 4-9 of the GR gene was carried out using other primer sequences (data not shown; sequences available on request), to obtain PCR fragments with a length of about 200 nucleotides. SSCP analysis of the PCR fragments was carried out as described above. Finally, PCR fragments of exons 4-9 (coding for the hormone-binding domain of the GR) in all patients and of the whole coding part of the GR gene in patients 1 and 2 were subjected to direct sequencing as described by Karl et al. (16).

\section{Patient 1}

\section{Results}

Patient 1 was first investigated at the age of $18 \mathrm{yr}$ because of hirsutism and menstrual irregularities. Physical examination revealed profound hirsutism on the arms, legs, chest, and face. She had a round face and acne and generalized obesity.

Endocrine testing showed an intact diurnal rhythm of plasma cortisol concentrations at an elevated level. 24-h urinary cortisol secretion was twice the upper limit of normal. Serum ACTH levels were in the higher normal range. A 1-mg overnight DEX suppression test (DST) showed insufficient cortisol suppression (323 nmol/L; N, <140 nmol/L). Additional studies showed increased androstenedione $(24.4$ $\mathrm{nmol} / \mathrm{L})$ and testosterone (3.4 nmol/L) levels. At that time, the diagnosis of pituitary-dependent Cushing's syndrome 
was made and a left-sided adrenalectomy was performed, followed by external pituitary radiation.

Twelve years after the first admission, the patient was screened with respect to cortisol receptor characteristics. It seemed that she had a normal number of receptors per cell in mononuclear leukocytes, and also the ligand-binding affinity of the receptors was normal (n, 7429 receptors / cell; $\mathrm{K}_{\mathrm{d}}$, $8.6 \mathrm{nmol} / \mathrm{L})$. From the mitogen-induced proliferation assay, however, it became clear that the PBMLs were insensitive to DEX (Fig. 1). PCR/SSCP analysis of the GR gene showed an abnormal pattern in the $\mathrm{N}$-terminal part of exon 2 . Sequence analysis of the fragment revealed the presence of a polymorphism, leading to a GAG to GAA (both Glu) in codon 22 and an AGG to AAG (Arg to Lys) change in codon 23, as described previously by Koper et al. (27). Further sequence analysis of the whole coding part of the GR gene revealed no additional alterations.

Based on clinical and biochemical findings, the diagnosis of generalized CR was made and a treatment with low doses of DEX (1 mg) at night was started. Cortisol, androstenedione, and testosterone levels normalized during DEX treatment, and there was a slight improvement of the hirsutism.

\section{Patient 2}

Patient 2, a girl born in 1976, presented at the age of $7 \mathrm{yr}$ with very severe asthma. When she was referred to our clinic at the age of $17 \mathrm{yr}$ she had been treated with $25 \mathrm{mg}$ prednisone daily continuously for $2 \mathrm{yr}$, which regularly had to be elevated to a dose of $60 \mathrm{mg}$ per day over a period of 10-12 days. Despite this therapeutic regimen, she still had severe complaints of asthma, not allowing her to live a normal life. Because of this very poor clinical response to therapy in the absence of the development of signs or symptoms of exogenous Cushing's syndrome, she was referred to our clinic for further investigation with respect to the GR gene.

Physical examination revealed a tall, slender young woman without signs or symptoms of Cushing's syndrome.

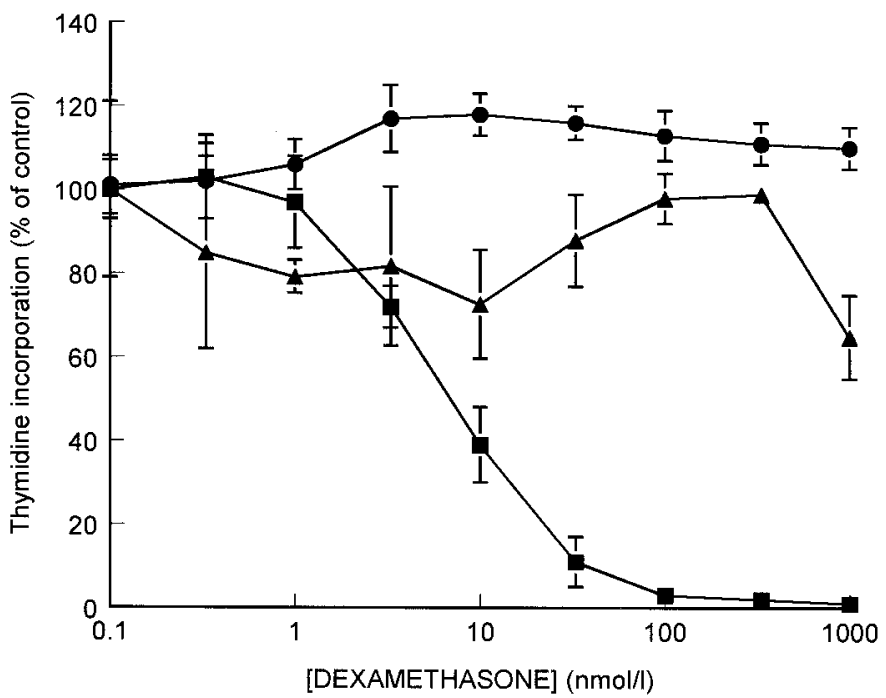

FIG. 1. Mitogen-induced proliferation assay in patient 1 (circles), patient 4 (triangles), and a healthy control (squares). In both patients DEX showed an absent capacity to inhibit mitogen-induced cell proliferation.
Despite continuous high-dose prednisone therapy during puberty, her final height was over $10 \mathrm{~cm}$ above the parents' height $(1.70 \mathrm{~m})$. Because of the high dose of prednisone the patient was taking, we were not able to perform regular testing of the HPA axis. Furthermore, as became clear from a previous study (23), prednisone is an agent that interferes with the whole cell DEX-binding assay and the mitogeninduced thymidine incorporation assay, making it impossible to obtain meaningful results from these tests.

Using PCR/SSCP analysis, we found the same polymorphism as described for patient 1 in exon 2 of the GR gene. No other mutations were found despite sequencing of the whole coding part of the GR gene.

The patient's family was tested with respect to CR as well. They were all healthy without clinical signs of GR. All family members showed a normal cortisol suppression in the 1-mg overnight DST. Nevertheless, it seemed that the grandmother, the mother, and the oldest brother showed the same polymorphism in exon 2 of the GR gene.

\section{Patient 3}

Patient 3 is a 65-yr-old man. Hypertension was diagnosed at the age of 50 . Fifteen years before presentation, a computed tomography (CT) scan revealed a tumor in the right kidney and a tumorous-enlarged right adrenal gland. He underwent a partial right-sided nefrectomy in combination with an adrenalectomy. Histopathological evaluation revealed an infiltrating clear-cell adenocarcinoma of the kidney and nodular adrenal hyperplasia.

Two years later, he presented with obesity and insulin resistance. Early morning cortisol concentration was 432 $\mathrm{nmol} / \mathrm{L}$ (normal), whereas 24-h urinary cortisol excretion was increased to 2 -fold over the normal range. Five years later, a CT scan revealed a nodule of $2 \mathrm{~cm}$ in a nodularenlarged left adrenal gland. There were no clinical symptoms of Cushing's syndrome.

Endocrine testing at that time showed normal serum cortisol levels with a normal diurnal rhythm and high normal ACTH concentrations. There was an insufficient suppression of cortisol in the overnight 1-mg DST (471 nmol/L). In response to the iv administration of $0.1 \mathrm{U} / \mathrm{kg}$ insulin, he developed hypoglycemia, followed by a just subnormal increase in cortisol levels (from 546 to maximally $687 \mathrm{nmol} / \mathrm{L}$ ).

Three years later, a CT scan confirmed nodular hyperplasia of the left adrenal gland. A CT scan of the pituitary revealed no abnormalities. At present, he is still asymptomatic without signs or symptoms of Cushing's syndrome.

In the whole cell DEX-binding assay, a normal number of GRs per cell in PBMLs were seen (6659 receptors/cell), whereas a diminished affinity for DEX existed with a $K_{d}$ of $22.3 \mathrm{nmol} / \mathrm{L}$ (Fig. 2). In the mitogen-induced proliferation assay, a maximal inhibition of $77 \%$ could be achieved with an $\mathrm{IC}_{50}$ of $33.1 \mathrm{nmol} / \mathrm{L}$, which is in the high normal range.

Using PCR/SSCP analysis of the whole coding part of the GR gene in combination with sequence analysis of the whole hormone-binding domain (exons 4-9), no alterations in the GR gene could be identified.

The patient's three sons and daughter were tested with respect to CR as well. One of the sons had an increased 24-h 


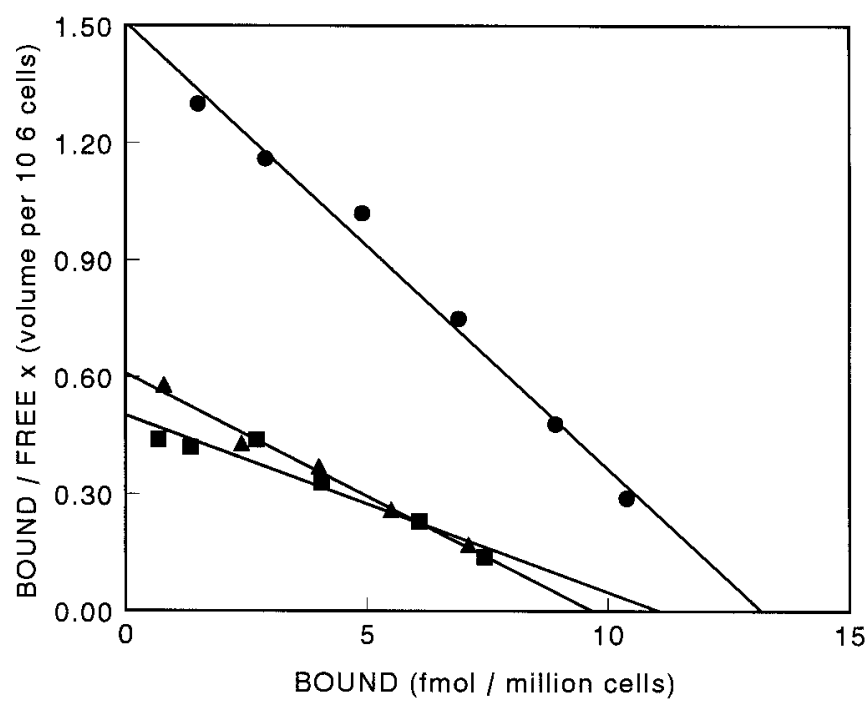

FIG. 2. Whole cell DEX-binding assay in patients 3 (triangles) and 4 (squares) and a healthy control (circles). Both patients showed a decreased affinity of the GR to DEX.

urinary cortisol excretion. He was a healthy young man with normal blood pressure. In the 1-mg overnight DST, an insufficient cortisol suppression occurred to $364 \mathrm{nmol} / \mathrm{L}$. Also in the son, no alterations in the GR gene were identified.

\section{Patient 4}

Patient 4 is a 33-yr-old schoolteacher who, over the past few years, developed irregular menstruations, acne, increasing hair growth on the face, increasing fatigue, and an unstable mood. Biochemical examination in another hospital pointed toward the existence of pituitary-dependent Cushing's syndrome. She underwent transsphenoidal pituitary surgery, during which normal pituitary tissue was removed. Because the complaints persisted, she was referred to our clinic.

Physical examination revealed a young woman without clinical stigmata of Cushing's disease. There was a slight increase in facial hair growth.

Endocrine testing revealed elevated early morning cortisol levels $(1355 \mathrm{nmol} / \mathrm{L})$ and a slightly disturbed circadian rhythm. 24-h urinary cortisol excretion was twice the upper limit of normal. The overnight DST revealed an insufficient cortisol suppression $(857 \mathrm{nmol} / \mathrm{L})$. ACTH concentrations were within the normal range. In response to the iv administration of $0.1 \mathrm{U} / \mathrm{kg}$ insulin, she developed hypoglycemia, followed by a normal increase in the basally elevated cortisol levels (from 920-1177 nmol/L), as well as of GH levels (from 3.0-19.7 $\mu \mathrm{g} / \mathrm{L}$ ). Additional studies showed normal serum androgen concentrations. Bone mineral density measurements showed a completely normal age- and sex-standardized level.

A whole cell DEX-binding assay, showed a normal number of binding sites per cell on PBMLs (5938 receptors/cell), but the ligand affinity of the receptors was significantly lowered ( $\mathrm{K}_{\mathrm{d}} 17.4 \mathrm{nmol} / \mathrm{L}$, Fig. 2). Also, in the mitogen-induced proliferation assay an insensitivity to DEX became apparent (Fig. 1).
PCR/SSCP analysis of the whole coding part of the GR gene showed no abnormal migration patterns. Furthermore, sequence analysis of the hormone-binding domain of the GR gene (exons 4-9) revealed no alterations in this part of the gene.

Her parents and only sister were healthy and showed a normal cortisol suppression in an overnight 1-mg DST.

Based on the clinical and biochemical data, the diagnosis of generalized CR was made. The patient has been treated with low doses of DEX ( $0.5 \mathrm{mg}$ overnight) for the past 12 months. Within a couple of weeks, a dramatic improvement of the clinical course was observed: fatigue and mental instability greatly improved. The patient started working again and jogs $10 \mathrm{~km}$ every other day. Cortisol concentrations remained elevated $(829 \mathrm{nmol} / \mathrm{L})$, and adrenal androgen production was slightly suppressed. Probably, this low dose of DEX was a sufficient dose to induce the clinical improvement in the patient, but was not high enough to completely suppress the HPA axis.

\section{Patient 5}

Patient 5 is a 33-yr-old woman who was admitted for analysis of severe tiredness, hirsutism, and oligomenorrhea. Furthermore, there were complaints of muscle weakness. She was no longer able to perform her job as a schoolteacher.

Endocrine testing showed a normal circadian rhythm of cortisol at a normal level, normal ACTH levels, and a normal urinary cortisol excretion. There was an insufficient cortisol suppression in reaction to the administration of $1 \mathrm{mg}$ DEX $(503 \mathrm{nmol} / \mathrm{L})$. A normal GH response in reaction to an insulin-induced hypoglycemia was observed (from 0.3-27.3 $\mu \mathrm{g} / \mathrm{L})$, but cortisol concentrations did not increase sufficiently (from 402-481 nmol/L). Serum androstenedione levels were increased $(27.2 \mathrm{nmol} / \mathrm{L})$. The patient had no brothers or sisters, and her parents were both healthy and showed normal cortisol concentrations and a normal adrenal cortisol suppression in an overnight 1-mg DST.

Analysis of cortisol receptor characteristics in mononu-

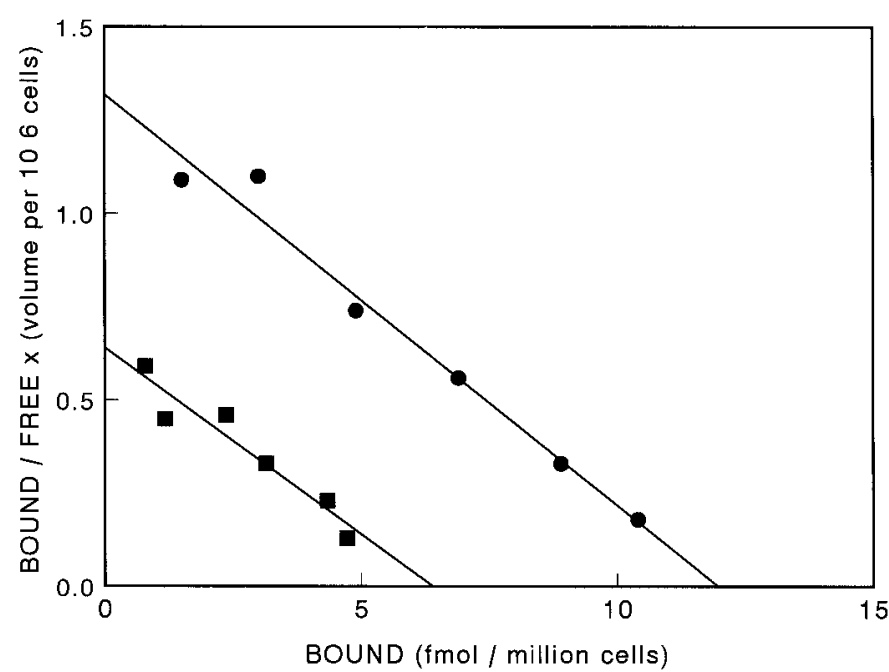

FIG. 3. Whole cell DEX-binding assay in patient 5 (squares) and a healthy control (circles). The patient showed only half of the normal receptor number per cell. 
clear leukocytes showed a normal $\mathrm{K}_{\mathrm{d}}(8.1 \mathrm{nmol} / \mathrm{L})$ in combination with a significantly lowered number of receptors per cell (3500 receptors/cell; Fig. 3). The bioassay showed a normal capacity to inhibit mitogen-induced proliferation $\left(\mathrm{IC}_{50}, 27.7 \mathrm{nmol} / \mathrm{L}\right)$. PCR/SSCP analysis of the whole coding part of the GR gene showed no abnormal migration patterns. Furthermore, sequence analysis of the hormone-binding domain of the GR gene (exons 4-9) revealed no alterations in this part of the gene.

Based on the clinical and biochemical finding, the diagnosis of partial CR was made. The patient has been treated with low doses of DEX (0.5 mg overnight) for the past 12 months. Androstenedione levels slightly decreased (to 17.6 nmol/L). Hirsutism has improved, and the menstrual pattern normalized. Furthermore, tiredness improved dramatically, and the patient feels well for the first time in years and started to work again on a regular basis.

\section{Discussion}

Ever since the first description 1976 by Vingerhoeds et al. (2), only about 30 patients and (asymptomatic) family members with CR have been described. Up until now, the molecular basis for CR has been described in six patients and affected (asymptomatic) family members (15-20). In all six cases, mutations in the hormone-binding domain of the GR gene were responsible for the clinical manifestation of $C R$. Recent reports of a considerable prevalence of possible abnormalities in the GR in patients attending the endocrine clinic for hypokalemia, hypertension, acne, hirsutism, and menstrual disorders $(1,11)$ prompted us to carry out a thorough investigation with respect to the GR protein and the GR gene in patients attending the endocrine clinic for a broad spectrum of complaints suggesting a possible CR. In the present study, we describe five patients with variable clinical presentation that all seem attributable to generalized CR.

All patients demonstrated an intact or nearly intact diurnal rhythm of serum cortisol concentrations, an insufficient suppression of serum cortisol concentrations in reaction to $1 \mathrm{mg}$ DEX, variable degrees of androgen overproduction, and the absence of clinical signs and symptoms related to long-term exposure of the body to increased cortisol production.

In patients 4 and 5, fatigue was (besides signs of hyperandrogenism) an additional complaint. In a previous report by Bronnegard et al. (5), a family with CR was described, in whom chronic fatigue was the only symptom. It was hypothesized that there was an insufficient compensation by increased GC secretion in certain target tissues, like, for example, the central nervous system. In patient 5, treatment with low doses of DEX improved the feelings of tiredness. In this patient, an insufficient increment of GC secretion to overcome the CR might be the explanation for the clinical picture.

Patient 2 was a young girl with severe steroid-resistant asthma. She had not developed adverse effects with respect to signs and symptoms of Cushing's syndrome. It was striking that there was no growth impairment during puberty, and her final length was well above her parents' length. Because of the GC therapy, we could not perform endocrinological testing nor determine receptor protein character- istics. Nevertheless, the CR diagnosis was based on the complete absence of signs and symptoms of Cushing's syndrome. The results of a number of studies (28-30) suggest that in cases of rheumatoid arthritis, asthma, and sepsis, high local concentrations of cytokines induce a localized CR at the site of inflammation, which can insufficiently be overcome by excess exogenous GCs. This reversible cytokine-induced form of CR should be differentiated from the situation in our patient in whom steroid-resistant asthma was probably due to an irreversible (generalized), which was previously described in two patients by Sher et al. (13). This differentiation can be made on the bases of the appearance of side effects: in patients with cytokine-induced CR, GCs do have deleterious systemic effects, whereas in patients with generalized CR no side effects of treatment with high doses of GCs are seen.

To search for possible alterations in the GR gene explaining the clinical pictures in the patients described in this study, PCR/SSCP analysis of the whole coding part of the GR gene was performed. Furthermore, the hormone-binding domain of the GR gene (exons 4-9) was screened using sequence analysis. Two of the patients described carried a polymorphism characterized by a double point mutation at codons 22 and 23. This polymorphism has previously been described in a general population screening by Koper et al. (27). In that study, a 1-mg overnight DST was performed in 216 healthy elderly individuals. The same polymorphism was found in this population study in eleven individuals, including the person with the highest post-DEX cortisol concentration (256 nmol/L). Moreover, two other subjects with diminished cortisol suppression (post-DEX cortisol concentrations were 110 and $241 \mathrm{nmol} / \mathrm{L}$, respectively) were found to carry the same mutation. However, eight other subjects out of this group of 216 volunteers, showed this polymorphism in combination with a normal cortisol suppression in reaction to $1 \mathrm{mg}$ DEX. From patient 2, we screened her family with respect to this polymorphism as well. It seemed that her healthy grandmother, mother, and brother carried the mutation. They all showed a normal cortisol suppression in the 1-mg DST. In in vitro expression experiments, this polymorphism showed no alterations in the efficacy of the GR to activate transcription in such systems compared to the wild-type receptor (31). Possibly, in the patients with CR carrying this polymorphism, the mutation is linked to another mutation/polymorphism in or near the GR gene that was not detected in our study using the PCR/SSCP/sequence approach.

In patients 3-5, who all showed clear clinical and biochemical pictures of CR, no GR gene alterations were found, however. It is clear that there is a discrepancy between the clinical and biochemical picture in these patients, on the one side, and the molecular characterization, on the other side. This is especially true for the patients who showed a lowered $\mathrm{K}_{\mathrm{d}}$. In these patients one would expect to find alterations in the hormone-binding domain of the GR gene. Patient 5 showed only half of the normal numbers of GR per cell in PBMLs. In a family with only half of the number of receptors previously described by Karl et al. (16), it seemed that this was due to a splice site mutation in one of the alleles of the GR gene, resulting in an unstable messenger RNA. Another possibility might be that there is a mutation/deletion in one 
of the alleles that alters the structure of the hormone-binding domain in such a way that no ligand can be bound. On the other hand, one would expect to find such alterations using $\mathrm{PCR} / \mathrm{SSCP} /$ sequence analysis.

Not only GR expression level and ligand-binding affinity, but also ligand-induced GR conformation changes, dissociation from heat shock proteins, phosphorylation, and nuclear transformation are important determinants of GC sensitivity (32). Another possibility could be that postreceptor defects or interactions with other nuclear cofactors form the pathophysiologic basis of CR in these patients. To investigate the GR gene more extensively, a next step will be to look at the transcriptional level by studying messenger RNA expression.

It can be concluded that in all five patients described, there was clinical and/or biochemical evidence for generalized CR. On the other hand, we could not identify GR gene alterations that give a molecular explanation for the clinical and biochemical CR.

\section{References}

1. Lamberts SWJ, Koper JW, Biemond P, et al. 1992 Cortisol receptor resistance: the variability of its clinical presentation and response to treatment. J Clin Endocrinol Metab. 74:313-321.

2. Vingerhoeds AC, Thijssen JH, Schwarz F. 1976 Spontaneous hypercortisolism without Cushing's syndrome. J Clin Endocrinol Metab. 43:1128-1133.

3. Chrousos GP, Vingerhoeds AC, Brandon D, et al. 1982 Primary cortisol resistance in man: a glucocorticoid receptor mediated disease. J Clin Invest. 69:1261-1268.

4. Lida S, Moriwaki K, Itoh Y, et al. 1985 Primary cortisol resistance accompanied by a reduction in glucocorticoid receptors in two members of the same family. J Clin Endocrinol Metab. 60:967-971.

5. Bronnegard M, Werner S, Gustafsson JA. 1989 Primary cortisol resistance associated with a thermolabile glucocorticoid receptor in a patient with fatigue as the only symptom. J Clin Invest. 78:1270-1278.

6. Lamberts SWJ, Poldermans D, Zweens M, et al. 1986 Familial cortisol resistance: differential diagnostic and therapeutic aspects. J Clin Endocrinol Metab. 63:1328-1333.

7. Nawata H, Sekiya K, Higuchi K, et al. 1987 Decreased deoxyribonucleic acid binding of glucocorticoid receptor complex in cultured skin fibroblasts from a patient with the glucocorticoid resistance syndrome. J Clin Endocrinol Metab. 65:219-226.

8. Vercei P, Frank K, Haack D, et al. 1989 Primary glucocorticoid receptor defect with likely familial involvement. Cancer Res. 49(Suppl):2220s-2221s.

9. Jaursch-Hancke C, Allolio B, Reincke M, et al. 1989 Primary cortisol resistance as a differential diagnosis of Cushing's syndrome. Acta Endocrinol Copenh. 120(Suppl):113.

10. Malchoff CD, Javier EC, Malchoff DM, et al. 1990 Primary cortisol resistance presenting as isosexual precocity. J Clin Endocrinol Metab. 70:503-507.

11. Werner S, Thoreu M, Gustafsson JA, et al. 1992 Glucocorticoid receptor abnormalities in fibroblasts from patients with idiopathic resistance to dexamethasone diagnosed when evaluated for adrenocortical disorders. J Clin Endocrinol Metab. 75:1005-1009.

12. Norbiato G, Bevilaqua M, Vago T, et al. 1992 Cortisol resistance in acquired immunodeficiency syndrome. J Clin Endocrinol Metab. 74:608-613.
13. Sher ER, Leung DYM, Surs W, et al. 1994 Steroid resistant asthma. Cellular mechanisms contributing to inadequate response to glucocorticoid therapy. J Clin Invest. 93:33-39.

14. Giguere V, Hollenberg SM, Rosenfeld MG, et al. 1986 Functional domains of the human glucocorticoid receptor. Cell. 46:645-652.

15. Hurley DM, Accili D, Stratakis CA, et al. 1991 Point mutation causing a single amino acid substitution in the hormone binding domain of the glucocorticoid receptor in familial glucocorticoid resistance. J Clin Invest. 87:680-686.

16. Karl M, Lamberts SWJ, Detera-Wadleigh SD, et al. 1993 Familial glucocorticoid resistance caused by a splice site deletion in the human glucocorticoid receptor gene. J Clin Endocrinol Metab. 76:683-689.

17. Malchoff DM, Brufsky A, Reardon G, et al. 1993 A mutation of the glucocorticoid receptor in primary cortisol resistance. J Clin Invest. 91:1918-1925.

18. Karl M, Lamberts SWJ, Koper JW, et al. 1996 Cushing's disease preceded by generalized glucocorticoid resistance: clinical consequences of a novel, dominant-negative glucocorticoid receptor mutation. Proc Assoc Am Physicians. 108:296-307.

19. Vottero A, Combe $\mathbf{H}$, Lecomte $\mathbf{P}$, Longui CA, Chrousos GP. A novel mutation of the glucocorticoid receptor in familial glucocorticoid resistance. Proceedings of the 81st Annual Meeting of The Endocrine Society, San Diego, CA, 1999, p 90 (Abstract).

20. Mendonca BB, Leite MV, Bachega TA, et al. Familial glucocorticoid resistance due to a novel mutation in the glucocorticoid receptor gene associated with a heterozygous large conversion of 21-hydroxylase gene causing female pseudohermaphroditism. Proceedings of the 81st Annual Meeting of The Endocrine Society, San Diego, CA, 1999, p 273 (Abstract).

21. Lamberts SWJ, Klijn JGM, de Jong FH. 1987 The definition of true recurrence of pituitary dependent Cushing's syndrome after transsphenoidal operation. Clin Endocrinol. 26:707-712.

22. Biemond P, de Jong FH, Lamberts SWJ. 1990 Continuous dexamethasone infusion for seven hours in patients with the Cushing syndrome. Ann Intern Med. 112:738-742.

23. Molijn GJ, Spek JJ, van Uffelen JCJ, et al. 1995 Differential adaptation of glucocorticoid sensitivity of peripheral blood mononuclear leukocytes in patients with sepsis or septic shock. J Clin Endocrinol Metab. 80:1799-1803.

24. Scatchard G. 1949 The attractions of proteins for small molecules and ions. Ann NY Acad Sci. 51:660-672

25. Huizenga NATM, Koper FJW, de Lange $\mathbf{P}$, et al. 1998 A polymorphism in the glucocorticoid receptor gene is associated with increased sensitivity to glucocorticoids in vivo. J Clin Endocrinol Metab. 83:144-151.

26. Orita M, Iwahana H, Kanazawa H, et al. 1989 Detection of polymorphisms of human DNA by gel electrophoresis as single-strand conformation polymorphisms. Proc Natl Acad Sci USA. 86:2766-2770.

27. Koper FJW, Stolk RP, de Lange $\mathbf{P}$, et al. 1997 Lack of association between five polymorphisms in the glucocorticoid receptor gene and glucocorticoid resistance. Hum Genet. 99:663-668.

28. Corrigan CJ, Brown JPH, Barnes NC, et al. 1991 Glucocorticoid resistance in chronic asthma: glucocorticoid pharmacokinetics, glucocorticoid receptor characteristics and inhibition of peripheral blood $\mathrm{T}$ cell proliferation by glucocorticoid in vitro. Am Rev Respir Dis. 144:1016-1025.

29. Corrigan CI, Brown JPH, Barnes NC, et al. 1991 Glucocorticoid resistance in chronic asthma: peripheral blood $\mathrm{T}$ lymphocyte activation and comparison of the T lymphocyte inhibitory effects of glucocorticoids and cyclosporin A. Am Rev Respir Dis. 144:1026-1032.

30. Spahn JD, Leung DY, Surs W, et al. 1995 Reduced glucocorticoid binding affinity in asthma is related to ongoing allergic inflammation. Am J Respir Crit Care Med. 151:1709-1714.

31. de Lange P, Koper FJW, Huizenga NATM, et al. 1997 Differential hormonedependent transcriptional activation and repression by naturally occurring human glucocorticoid receptor variants. Mol Endocrinol. 11:1156-1164.

32. Bamberger CM, Schulte HM, Chrousos GP. 1996 Molecular determinants of glucocorticoid receptor function and tissue sensitivity to glucocorticoids. Endocr Rev. 17:245-261. 